\title{
Little Housebound : an early Ngaio Marsh play and its manuscripts
}

\author{
Jane Stafford
}

In 1919, Ngaio Marsh, then aged 24, was invited to join the Allan Wilkie Shakespeare Company for its 1919-20 New Zealand tour. During 1920 and 1921 she toured with the Rosemary Rees English Comedy Company. After a brief run, the latter 'yielded to high costs and a small population and quietly folded' (Marsh 143). Marsh returned to her parents' home in Cashmere, Christchurch, and her friend, Kiore (Tor) King came to stay:

We talked endless theatre and presently I started to write sketches and we both began to think that they might do and that it would be fun to try them out if we could find someone for the men's parts. (143)

The Marsh family had a long-standing enthusiasm for amateur dramatics. Her grandfather E.W. Seager, was involved in drama productions of the Christchurch Workingmen's Club and the Sunnyside Dramatic Class, ${ }^{1}$ her parents were keen amateur actors, and Marsh had already written one very successful play while still at school. The Moon Princess was produced in 1913 in St Michael's school hall, and was described by the Christchurch Press as 'a clever little play' (Lewis 19). ${ }^{2}$ Allan Wilkie's interest in her had been prompted by her showing him the script of another early work, The Medallion, which, she said later, 'was derived without prejudice from Shakespeare, Sheridan, Wilde and Baroness Orczy'. (113)

The result of Tor King's visit was a play, at first called Come out and play, later renamed Little Housebound. Marsh says in her autobiography that she kept no copy of Little Housebound, but she gives a remarkably full, if slightly satirical version of it:

The plot is simple and derivative. There is, as present idiom goes, this Boy and he is a Woodsman and he is Kind of Restless and feels the call of the Great Forest and the World Outside and there is this Girl he is going to marry and she is frightened of the world outside and so when she has prepared his supper she drops off to sleep in front of the fire and her boyfriend has a soliloquy while he listens to the wind going "ohe" round the hut and he gets to thinking there is Somebody Out There, abroad in the forest. So he opens the window and calls out for whoever it is to come in and so Pierrot comes in, all wet with the Rain outside and is very fey and talks about the Stroller's life and says it is Gay, in the original sense. Pierrette comes in and she is also very gay 
and fey, although damp, and speaks in broken English but not the same kind as Anna in The Luck of the Navy ${ }^{3}$. And she fascinates the Boy and she and Pierrot tell him he is One of Them and she looks at the sleeping girl and makes disparaging remarks about her. So the Boy feels the Call of the Outside which is somewhat heavily symbolised by Pierrot and Pierrette, and is tempted and works up to a climax and they forget to keep their voices down and the Girl wakes up and is frightened by their white faces. And they go silent and symbolic and stare at the Boy as they move backwards into the window and he says to the Girl not to be frightened, he will never leave her, no, no, no, staring at Pierrot and Pierrette. So they vanish through the window and the storm dies down. The Boy speaks the tag, "They are all singing. They will soon be up on the shoulder of the hill." (144)

Her recall here is theatrical rather than textual. She remembers movements, stage directions and theatrical effects rather than dialogue. Her detail may be slightly wrong-in the two surviving manuscripts, Pierrette enters before Pierrot-but her recollection of how the play looked and felt is acute.

When she had finished writing it, she and Kiore King addressed the problem of the male role. Jimmy, a member of the Rosemary Rees Company, was contacted and shown the script:

We read the play and he and Tor looked at each other and with one voice ejaculated "Havelock North. (145)

Havelock North was a small township in Hawkes Bay with artistic pretensions which, as Marsh puts it, had 'become a cultural centre or thought of itself as such...Little Housebound was the very stuff on which Havelock North culture blossomed'.(145) The tour was mounted with some success:

We actually made some money. He [Jimmy] then interviewed the cinema management and we were given a tour, taking up half the programme and a share of the house.(145)

Despite Marsh's claim that she kept no copy of Little Housebound, there is a version of the play in her papers in the Turnbull Library, Wellington. Most of this collection came to the library after her death in 1982. However, Little Housebound may have been acquired independently. Items already in the library's possession or acquired later were incorporated into the collection without being identified in any way in the catalogue. ${ }^{4}$

Marsh's biographer Margaret Lewis seems to refer to the Turnbull version when she discusses the play: 
In Little Housebound Carol is wondering at the power the woods exert over him and his desire for freedom puzzles and unsettles him:

...it is as though there were two Carols. There is the Carol that loves home and you, and the smell of woodsmoke, and all the warm house-bound things; but most of all you, my sweet. But there is another Carol and he loves the hills and the long roads stretching away at dusk. He wants to follow them to the world's end in search of something that he can never find. (261)

Lewis's footnote cites 'Marsh papers, ATL', referring back to an original fuller note, 'Dame Ngaio Marsh Papers in Alexander Turnbull Library, National Library of New Zealand, Ref. 1397' (260). The 'Ref. 1397' is the general library callmark for Marsh's papers. The material is diverse, and is roughly organised in subject categories designated 'series'. Series IV contains playscripts and production notes, divided into numbered folders. The catalogue contains a description of the contents of each folder. Little Housebound is mentioned twice, in the description of folder 16, and in the description of folder 38 . The second reference here is puzzling as folder 38, described as 'Production and miscellaneous material for various plays', contains nothing relating to Little Housebound. The entry, which demonstrates the wide range of material, reads:

Scope and contents: Production and miscellaneous theatre material including income statement for 'Twelfth Night'; cast list for 'King Henry $V^{\prime}$ ' (1972) productions; pencil sketches of device for curtain and list of Shakespeare plays reduced to 23,000 lines; measurements of NZ stages for a 'Macbeth' production. Also an unidentified play at end of folder $1 \mathrm{~b}$ 'Little housebound" written in front and play text pasted in rear.

The reference here to Little Housebound seems to be a mistake, probably a mistranscription of ' 16 ', that is folder 16 , which contains the play, as ' $1 b^{\prime}$, which was interpreted as being a separate folder. This may have been grouped with folder 38 , because of its subject matter. ${ }^{5}$ The description of the 'folder' (in fact an exercise book) as 'written in front and play text pasted in rear' corresponds to the manuscript in folder 16, The Moon Princess being the other play. As far as can be ascertained, there is only one version of the play in the library's collection.

This makes Lewis's reference to the text of the play puzzling. She has not used the text in the Turnbull, as there is no speech in the library's manuscript corresponding to the one she quotes. The closest equivalent is on page 5, and reads 
The Boy Oh silly little thing - of course I would never go away from you (He looks over his shoulder through the window \& then back to her) I - I - would not want to. I - it was only stupid talk - praps gnomes or fairys put it in my head or praps I'm talking nonsense because I am so hungry There - there please Colette dear dont cry any more.

There are many corrections in this passage, more than is usual in the manuscript as a whole, suggesting an uncertainty and dissatisfaction on the part of the author, and from 'talk - praps gnomes or fairys...' to the end, the handwriting and ink are slightly different, possibly a later addition by Marsh. The speech Lewis quotes sounds far more polished, suggesting that she was using a later version.

Lewis gives the boy's name as Carol. In the Turnbull manuscript, he is initially called Priam, but this is changed to Prosper. The girl is initially Annette, changed to Colette. The Turnbull manuscript shows signs of being a compilation of an earlier version and a later revision. Marsh has used a foolscap hard-backed exercise book with lined paper to which, for the first five pages, she has glued unlined sheets on which the play is hand-written. Corrections to the glued-in text are made in different coloured ink and slightly different handwriting. Corrections are generally minor, chiefly the name change. Page 6 is written directly on to the lined page of the exercise book in the same handwriting and ink as the later emendations; page 7 is glued in. The remaining pages (8-20) are written directly into the exercise book, 18, 19 and 20 being in pencil rather than ink, and the final page of the play (page 21) is on a loose sheet in a faint and different hand. There are no illustrations .

Where, then, did Lewis's version come from? After its triumphant Havelock North tour, Little Housebound was performed by the Wauchop School of Drama and Dancing in 1924, and by the Canterbury Repertory Society in 1931 (Lewis 34). Thus, there could very well be a number of copies of the script in private hands.

At least one such copy is known-an early version, which belonged to Kiore King, though the dedication suggests that it was initially given to her mother, who accompanied the actors on their tour. This text is typewritten and complete. There is a dedication on the frontispiece in Marsh's handwriting:

To the nicest Auntie I've got

with my love

Ngaio

It is dated 'January 22nd 1922'. On the opposite page, in a later, different hand is written 'Marjorie Brooks, 12 Alexander St, Tauranga', Kiore King's sister-in-law, who owned the manuscript after King's death. ${ }^{6}$ 
There are twenty-two illustrations. Seven occupy the full page, and are coloured-pencil and water colour. The frontispiece, of a cottage in the depths of the forest, is painted directly onto the same heavy paper as the typescript and occupies the entire page, as does the second to last illustration on page 20. The remaining colour illustrations are smaller, painted on white and mounted on grey paper, sometimes within a narrow black boarder. All illustrate specific scenes from the play: Prosper gazing through the window, Pierrette appearing at the door, a portrait of Pierrette, a portrait of Pierrot, and two of the final scene-Prosper and Collette in each other's arms as Pierrot and Pierrette disappear through the door. The remaining illustrations are of various sizes and styles: two are large, carefully finished and mounted, one of Prosper and Pierrette, and one of Prosper, Pierrette and Pierrot. These two are done in charcoal. The remaining pictures are less formally conceived, small pencil sketches on the left-hand page facing the text: two faces (presumably Pierrette and Pierrot) peering from the trunk of a tree; Collette sitting disconsolately by the fire, a will-o-the-wisp spirit above her; a windblown Pierrette at the door; Pierrette and Pierrot sleeping in the forest; a figure in a hanging wicker cage (presumably to illustrate Pierrette's speech on the facing page, 'And so she is to tame you; to put you in a nice wa [sic] warm comfortable prison...eh?'); two steaming tankards; Prosper and Pierrette kissing; a rather vaguely defined fairy or sprite; Prosper looking into the distance; and Prosper crouched in an attitude of grief. All are by Marsh herself, the frontispiece being signed in pencil ' $\mathrm{Na} M A R S H$ ' in the right-hand corner.

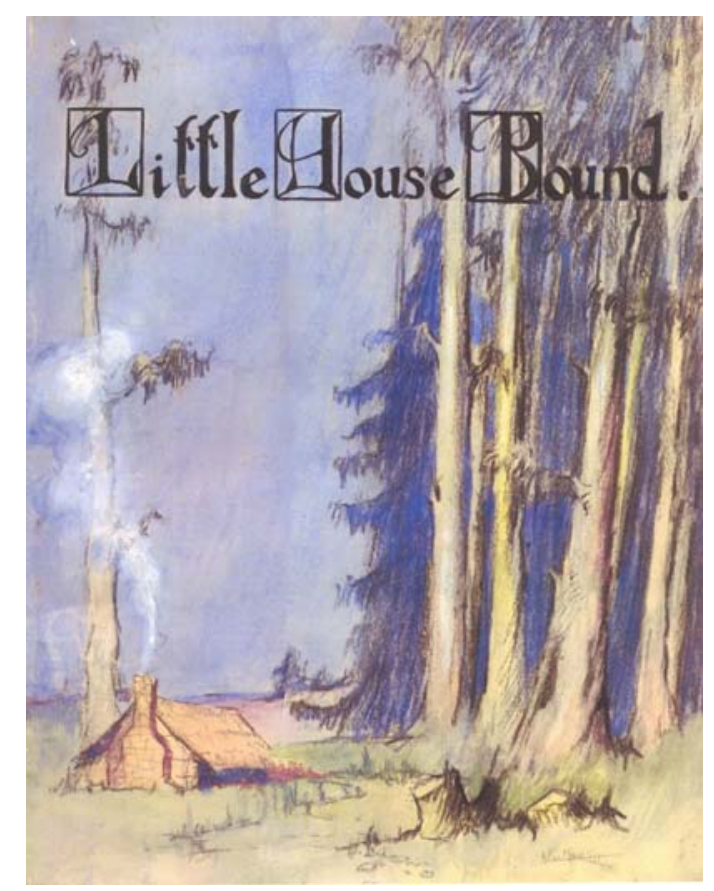

Kōtare 2, no. 1 (1999), pp. 19-29. 

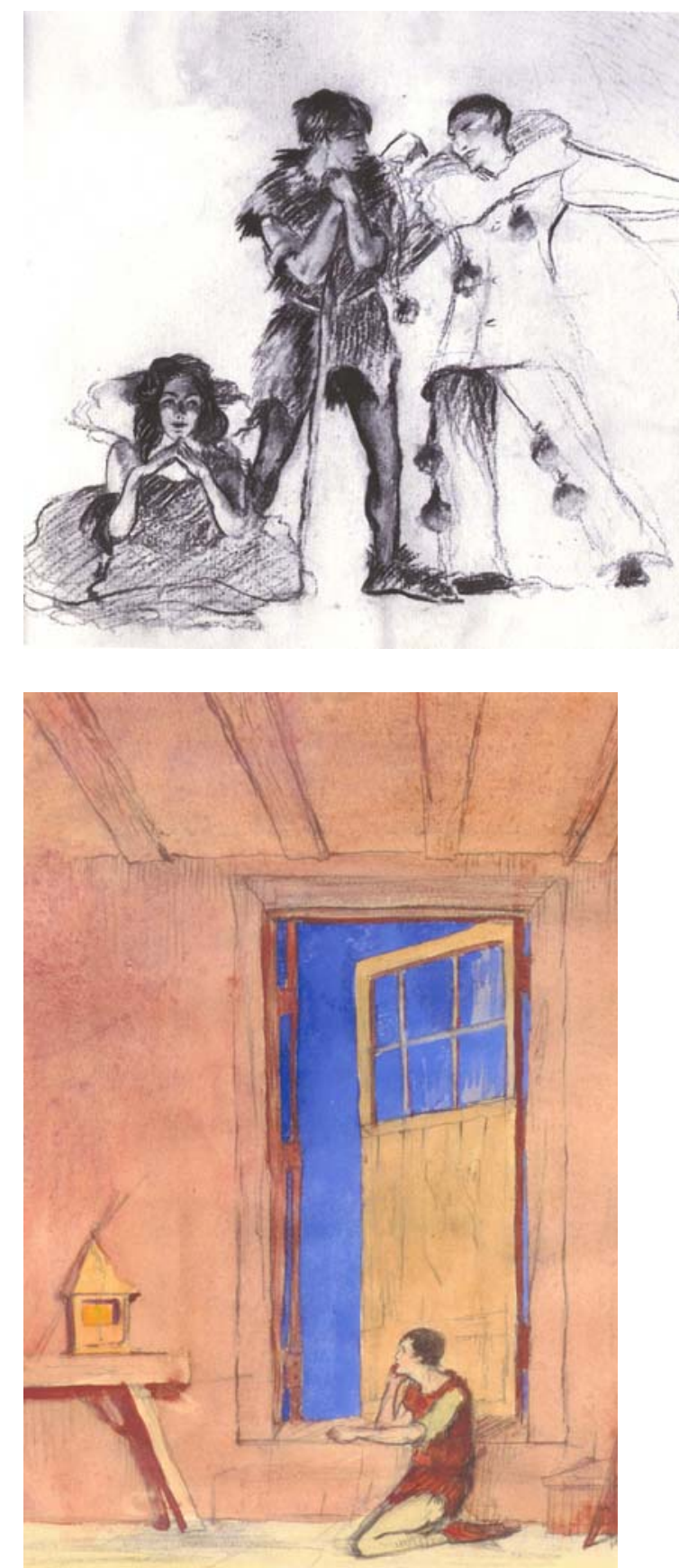

Kōtare 2, no. 1 (1999), pp. 19-29. 

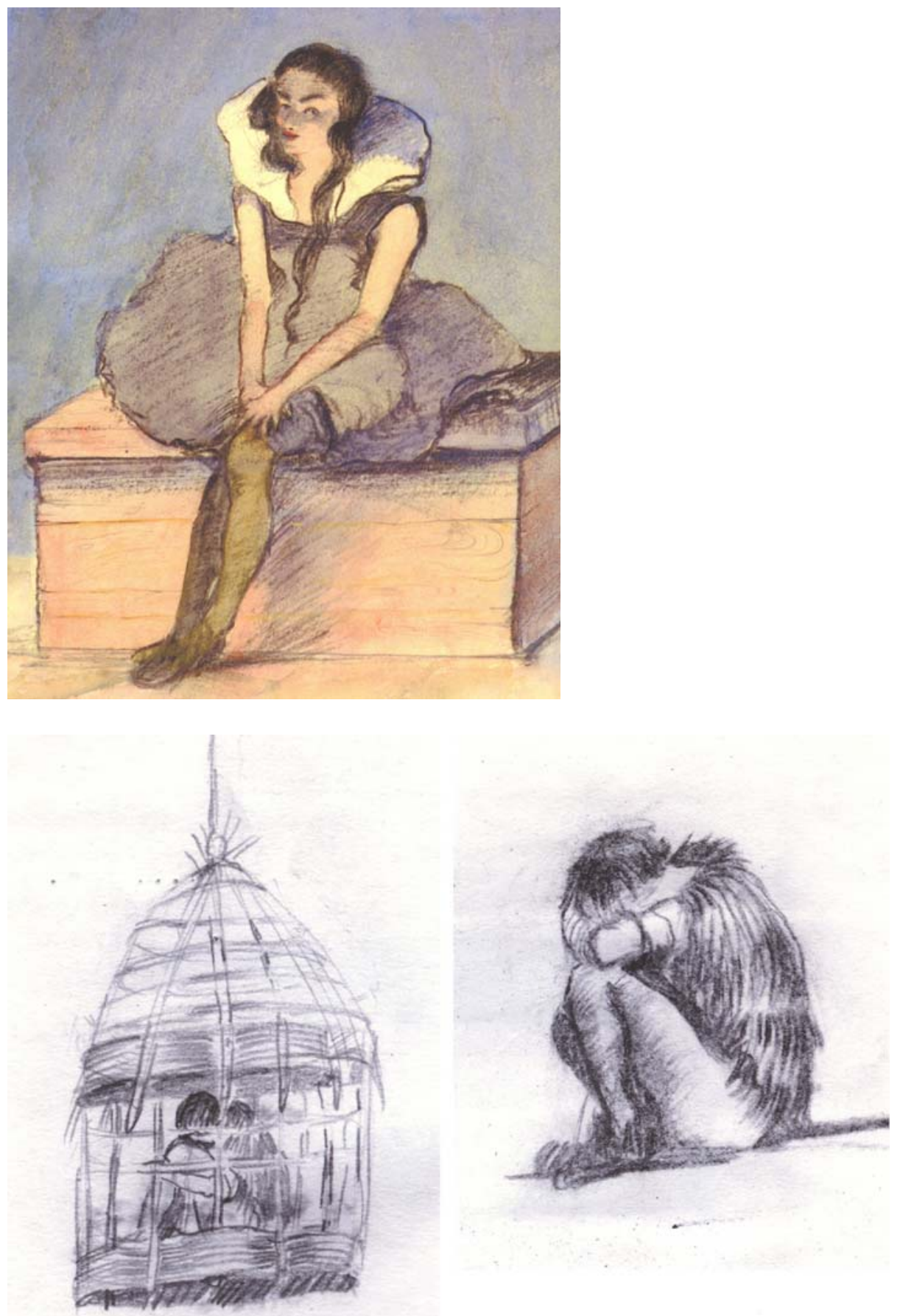

The finished form of this version-typed, illustrated, with a formal dedication-suggests that this was a presentation copy, given after the play's tour, as a memento. It does not have any of the kind of revisions and emendations that in the Turnbull version suggest textual evolution, or any of the director's notes and reminders that Marsh's working texts display. ${ }^{7}$ But this version is not the one Lewis quotes. The characters' names are in accordance with the revision of the Turnbull manuscript-Prosper and Collette, rather than Priam and Annette, with no mention of 'Carol'. And although there is a version of the speech Lewis quotes, it is not identical:

Kōtare 2, no. 1 (1999), pp. 19-29. 
Why Colette darling do not cry. It was only foolish talk. Just nonsense like a fairy tale. Do not cry. You see it is as if there were two Prospers. There is the Prosper that loves you: and home: and the smell of woodsmoke: and all the warm house-bound things but most of all you my sweet. And then there is another Prosper: and he loves the hills and the long roads stretching away, away in the dusk; and he wants to journ [sic] along them to the worlds [sic] end in search of something he can never find. (3)

So, Marsh has a near-perfect, if slightly self-mocking memory of the text, but claims in her autobiography not to have kept a version. There is however a version in her papers in the Turnbull Library. Lewis quotes from a version she claims is the one in the Turnbull collection, but it isn't. And although there is at least one other full text in private hands, it is not the one Lewis quotes.

How important is Little Housebound as a piece of literature? Lewis seems to have her doubts, and uses it only to serve her biographical purposes, by linking the play's escapist theme with what was happening in Marsh's life at the time it was written:

...the play is obviously more sophisticated in style than 'The Moon Princess' but it has a similar theme, expressing a desire to escape from the confines of the safe, ordinary world and seek freedom in the woods. Originally entitled 'Come out and Play' the piece is rather overromantic, but contains some interesting ideas that relate to the author's state of restlessness at the time. The ultra-conservative society of Christchurch and the subtle dominance of her mother- 'she was over-concentrated on me' - led Ngaio to dream consistently of a world of freedom beyond the familiar limits of home. (32)

Lewis goes on to connect 'the two-sided character in Little Housebound with his longing for freedom and adventure' to a 'dichotomy in Ngaio's subconscious' played out in later years in her divided time between Britain and New Zealand. his interpretation of the play seems simplistically psychoanalytic, and ignores its literary context. Marsh's own analysis is more sophisticated. In her autobiography, she identifies her influences and susceptibilities as 'the nebulous-romantic-pictuesque-Borrowesque ... Pierrot was not a dirty word and Granville Barker's Prunella had wrought its blameless spell.' (144) She describes her play as 'a sort of Prunella in reverse.' The fact that George Borrow's fictional autobiographies and spurious histories, The Zincali, or an account of the Gypsies in Spain (1841), Lavengro (1851) and The Romany Rye (1857) were still influential in 1920s New Zealand is interesting. Harley Granville Barker(1877-1946) is better known now in theatre history as the director and champion of Ibsen and Shaw. In 
New Zealand his significance is as the originator of the British Drama League, an important force in amateur theatre from the $1920 \mathrm{~s} .{ }^{8}$ But Marsh reminds us that he was also a dramatist. His play Prunella, or Love in a Dutch Garden (1910) was written in collaboration with Laurence Houseman. It uses the antithesis between confinement and escape as Marsh does in Little Housebound, but has a more elaborate plot. Unlike Prosper/Priam/Carol, Prunella succumbs to temptation, leaves the safety of her home and the tutelege of her aunts Prim, Prude and Privacy, and follows Pierrot and his band of roguish mummers. Pierrot's love proves inconstant and she returns to her now overgrown garden, only to be somewhat improbably reunited with him. A contemporary critic described Prunella as an 'exquisite little fantasy....full of quaint invention, humour, irony and pathos' despite what, to a modern reader, seems a decided undertone of Wildean decadence. ${ }^{9}$

Marsh's sources, both in Little Housebound, and in her earlier plays, The Medallion ${ }^{10}$ and The Moon Princess, are Victorian and Edwardian, reworking nineteenth century modes in a context best described as provincial rather than explicitly post-colonial. There is no self-conscious sense of place and only a slight sense, in hindsight, of the incongruity of Pierrot and Pierrette in the antipodes. The London stage is the centre, and the English literary tradition the model, although both are conceived as they had been a generation earlier. The local has force only in terms of reception-it provides audiences, bookings and earnings. Although the tone of Marsh's autobiographical account written in the 1960s and revised in the $1980 \mathrm{~s}^{11}$ suggests she sees the datedness of her play, 1920s Havelock North obviously did not.

Even on her own terms-that of the biographer-we might want to question the use Lewis makes of Little Housebound's themes of escape and confinement. At the time it was written, Marsh had just finished two theatrical tours with professional theatre companies. After it was written, she set up what was in effect her own company, and toured her own play in the provinces, with artistic and financial success. While it would be naive to take an author's account of their own life at face value, Marsh's description of this period does not sound confined. The chapter of her autobiography which describes it is called 'Winter of Content'. Lewis is trying, as all good biographers should, to construct a focused narrative from her subject's life. Tension between Marsh and her parents, and the boredom of Marsh's early life-before she was 'saved' by writing-is her central theme. Her reading of Little Housebound is, perhaps, unduly influenced by these factors.

We might also wish to re-examine Howard McNaughton's assertion that 'Marsh returned from Fine Arts Studies abroad with a set of theatrical axioms which would govern her work, and that of the actors she directed throughout 
her career' (335). ${ }^{12}$ Marsh returned from her first visit to Britain in 1932. As this account of Little Housebound suggests, her dramatic experience-as an actor, a dramatist and as a director-was extensive before she left, whereas the theatrical axioms that governed her work were fostered in the dramatic culture already existing in New Zealand.

\section{WORKS CITED}

Dictionary of New Zealand Biography:Volume 1: 1769-1869. Gen. Ed. W.H.Oliver. Wellington:Allen \& Unwin / Department of Internal Affairs, 1990.

Granville Barker, Harley and Houseman, Laurence. Prunella, or Love in a Dutch Garden. London: Sidgewick and Jackson, 1910.

Lewis, Margaret. Ngaio Marsh: A Life. London: The Hogarth Press, 1992.

Marsh, Ngaio. Black Beech and Honeydew. London: Collins, 1966, rev. ed. 1981.

${ }^{1}$ See Dictionary of New Zealand Biography, volume 1, Wellington:Department of Internal Affairs, Allen \& Unwin,1990,p.385.

${ }^{2}$ The manuscript of The Moon Princess is in the Marsh papers in the Alexander Turnbull Library. It has no title, but the plot indicates its identity fairly clearly.

${ }^{3}$ A play in which Marsh performed with the Allan Wilkie Shakespeare Company, see Marsh, 122.

${ }^{4}$ There is no information as to the provenance of Marsh's papers acquired before 1982 . The catalogue simply refers to 'MSS drafts and playscripts already held'.

${ }^{5}$ I am grateful to Margharita Gee of the Turnbull Library Manuscript Section for deducing this.

${ }^{6}$ The name and address are written in ball-point pen, rather than the ink of Marsh's dedication. My assumption is that this indicates that it was written later than 1922.

${ }^{7}$ See for example, the untitled play, probably The Moon Princess, in the same exercise book which contains Little Housebound. Comments such as 'Pause here', 'Ready Collette', 'Ready moonbeams and bats' dance' are written in the text in red ink and pencil.(Marsh Turnbull papers 1397 series IV, 16).

${ }^{8}$ There is a discussion of the British Drama League by Howard McNaughton in 'Drama', The Oxford History of New Zealand Literature in English, new edition, edited by Terry Sturm, Auckland: Oxford University Press, 1998, p.332.

${ }^{9}$ William Archer in the Tribune, quoted in the frontispiece of the 1910 edition.

10 'Shakespeare, Sheridan, Wilde and Baroness Orczy'. See above.

Kōtare 2, no. 1 (1999), pp. 19-29. 
${ }^{11}$ The phrase 'Gay, in the original sense' is a revision for the 1981 version of Marsh's autobiography, gay in the modern sense having appeared in the language during the late 1970s.

${ }^{12}$ Marsh studied art in Christchurch, at the Canterbury College School of Art from 1915 to 1919, not, as McNaughton states in Britain where, during her first visit from 1928 to 1932 she stayed with friends, wrote travel journalism for New Zealand newspapers, and for a time ran a shop. 